\title{
ANALISIS IDENTIFIKASI MASALAH DENGAN \\ MENGGUNAKAN METODE FAILURE MODE AND EFFECT ANALYSIS (FMEA) DAN RISK PRIORITY NUMBER (RPN) PADA SUB ASSEMBLY LINE (Studi Kasus : PT. Toyota Motor Manufacturing Indonesia)
}

\author{
Nia Budi Puspitasari, Ganesstri Padma Arianie, Purnawan Adi Wicaksono
}

Program Studi Teknik Industri, Fakultas Teknik, Universitas Diponegoro

Jl. Prof H. Soedharto, SH, Kampus Undip Tembalang, Semarang, Indonesia 50275

(Received: April 21, 2017/Accepted: July 17, 2017)

\begin{abstract}
Abstrak
Tingkat kegagalan (defect) merupakan suatu permasalahan yang selalui diupayakan untuk diminimasi oleh suatu perusahaan guna meningkatkan kualitas dari produk yang dihasilkan, begitu pula yang dilakukan oleh Toyota Motor Manufacturing Indonesia (PT. TMMIN) yang berkonsisten dalam menghasilkan produk berkualitas. Mengetahui bahwa pada Tahun 2016 terdapat defect GAP sebesar 50 ppm, maka perusahaan perlu melakukan identifikasi terhadap kegagalan yang terjadi di perusahaan. FMEA merupakan salah satu metode yang secara terperinci melakukan identifikasi dan analisis terhadap moda kegagalan hingga dapat diketahui penyebab dan dampak dari tiap kegagalan yang ada, sehingga didapatkan usulan perbaikan yang tepat. Studi kasus menggunaan FMEA pada PT. TMMIN menunjukkan adanya berbagai moda kegagalan pada assembly-line hingga diketahui alternatif perbaikan untuk setiap kegagalan yang menjadi prioritas perbaikan. Kegagalan yang menjadi prioritas tersebut dapat terlihat dalam bentuk Risk Priority Number (RPN). Berdasarkan RPN yang dihasilkan, didapatkan kegagalan prioritas untuk assemblyiline pada PT. TMMIN adalah adanya kesalahan pemasangan part, kegagalan akibat adanya benda asing pada part, dan kegagalan pada kesalahan perakitan piston.
\end{abstract}

Kata kunci: Cacat (Defect), FMEA, RPN, Kualitas, Manajemen Resiko

\begin{abstract}
The failure rate is a problem that has always attempted to be minimized by a company in order to improve the quality of products, and also were conducted by oleh Toyota Motor Manufacturing Indonesia (PT. TMMIN) which is consistent in producting a quality product. Knowing that in 2016 there is a defect GAP at $50 \mathrm{ppm}$, PT. TMMIN needs to identify the failures that occur in their company. FMEA is a method to identify and analyze the failure modes in detail that can able to know the cause and impact of each failures, so we get the proper repairment. FMEA that is used in PT. TMMIN case study indicate various modes of failure in assembly-line, then known the alternatives to repair for any prioritize failures. The priorities failures can be seen in the Risk Priority Number $(R P N)$. Based on the RPN resulting, we can obtain the priority failures in assembly-line of PT. TMMIN that are about the part installation errors, failures due to foreign objects in the part, and the failure of the piston assembly errors.
\end{abstract}

Keywords: Defect, FMEA, RPN, Quality, Risk Management

Pendahuluan

Indonesia merupakan salah satu negara dengan bisnis industri otomotif yang sangat berkembang, yaitu terbesar di ASEAN setelah

\footnotetext{
${ }^{*}$ Penulis Korespondensi.

email: niabudipuspitasari@gmail.com
}

Thailand. Bisnis dijalankan untuk dapat memperoleh keuntungan yang besar bagi perusahaan. Selain itu, bisnis dilakukan untuk mencapai tingkat kepuasan pada konsumen. Tingkat kepuasan konsumen tersebut menjadi salah satu poin penting yang dijadikan prioritas utama bagi perusahaan untuk dapat memenangkan persaingan yang ada. Perusahaan harus mampu mempertahankan kualitas produk sehingga dapat 
mempertahankan kepuasan pelanggan dan dapat memaksimalkan keuntungan.

Produk didefinisikan sebagai sesuatu yang ditawarkan dalam pasar sehingga dapat memenuhi kebutuhan dan kepuasan pelanggan (Kotler \& Keller, 2011). Kualitas suatu produk dianggap sebagai sesuatu yang harus selalu dikontrol dan diinspeksi untuk memenuhi kebutuhan konsumen (Weckenmann, Akkasoglu, \& Werner, 2015). Kualitas merupakan proses yang dinamis bukan merupakan 'static goal' (Saad \& Siha, 2000). Menurut Feigenbaum, kualitas merupakan keseluruhan dari karakteristik dari produk dan jasa yang meliputi marketing, engineering, manufacture, dan maintenance dimana produk dan jasa tersebut dalam pemakaiannya akan sesuai dengan kebutuhan dan harapan pelanggan. Dari penjelasan tersebut, terlihat bahwa kualitas harus meliputi seluruh aspek yang dilakukan perusahaan dalam menjalankan aktivitasnya, bukan hanya mempertahankan kualitas pada lantai produksi saja.

PT. Toyota Motor Manufaktur Indonesia (PT. TMMIN) merupakan salah satu industri otomotif yang sangat berkembang di Indonesia. PT. TMMIN berusaha mencapai kepuasan pelanggannya dengan cara menjaga kualitas produk yang diberikan. Kecacatan dalam suatu produk yang dihasilkan, sangat mempengaruhi tingkat kualitas dan kepuasan pelanggan terhadap produk yang dihasilkan. Cacat merupakan produk yang tidak dapat memenuhi spesifikasinya, atau tidak sesuai dengan standar kualitas produk yang seharusnya terpenuhi (Khodijah, 2015). Cacat/ defect tersebut yang berusaha dikurangi oleh bidang quality control dari PT. TMMIN. Pada PT. TMMIN terdapat test bench room yang berfungsi untuk melakukan pengecekan akhir dari perakitan mesin tipe $T R$ dan $T R-K$ sebelum mesin dikirim dan dirakit pada badan mobil.

Grafik yang menunjukkan tingkat defect yang terdapat pada test bench room dapat dilihat pada Gambar 1.

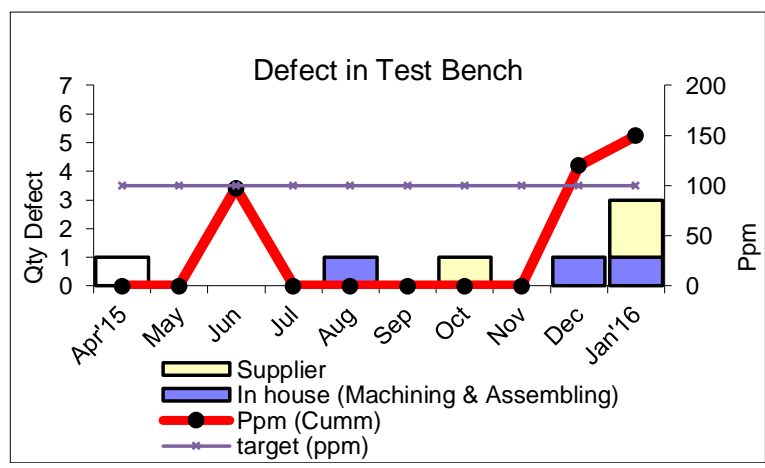

Gambar 1. Grafik Defect pada Tes Bench Room

Berdasarkan grafik pada Gambar 1, menunjukkan bahwa pada test bench room ditemukan nilai ppm pada bulan Desember 2015 dan Januari 2016 berada di luar batas ppm, yang mana batas ideal defect pada test bench room adalah 100 ppm. Munculnya defect pada test bench room tersebut dapat disebabkan oleh cacat material yang didapatkan dari supplier dan atau dikarenakan terjadi cacat pada saat proses machining dan assembly yang dilakukan di lantai produksi PT. TMMIN.

Diketahui bahwa in process defect pada test bench room di bulan Januari 2016 adalah 150 part per million (ppm), sehingga diketahui terdapat GAP sebesar 50 ppm antara ideal condition dan current condition.

Perusahaan berupaya untuk selalu mengontrol dan meningkatkan kualitas hasil produksinya, yaitu dengan mengurangi defect yang dihasilkan. Pada penelitian sebelumnya yang dilakukan oleh Mayangsari, Adianto dan Yuniati (2015), menunjukkan bahwa Metode Failure Mode and Effect Analysis (FMEA) berhasil digunakan untuk mengidentifikasi kegagalan produk berdasarkan potential cause pada perusahaan industri manufaktur. Sehingga, peneliti mengunakan metode FMEA untuk mengatasi masalah pada PT. TMMIN.

FMEA merupakan teknik analisa yang baik digunakan perusahaan untuk mencegah dan menghilangkan defect yang muncul dengan cara melihat hubungan sebab dan akibat dari defect, serta mencari pemecahan dengan tindakan yang tepat. FMEA dilakukan sebagai metode pendukung dari studi penilaian resiko dan pengidentifikasian potensi bahaya (Dudek \& Burlikowska, 2011). Metode ini tepat digunakan dalam menemukan solusi yang tepat dalam pemecahan masalah dari PT. TMMIN.

\section{Metodologi}

Menurut The European Foundation for Quality Management, manajemen resiko merupakan suatu proses sistematis yang melakukan identifikasi, menilai, mengelola dan memantau adanya resiko (Williams, et al., 2006).

Penelitian ini dilakukan untuk melihat resikoresiko yang ada pada PT. TMMIN berupa moda kegagalan yang mungkin terjadi dengan penilaian resiko paling tinggi hingga paling rendah.

Pengamatan dilakukan pada assembly line PT. TMMIN, yang terdiri dari sub-line Piston, sub-line Cylinder Block, sub-line Head, dan main line. Peneliti melakukan pengamatan yang dimulai dengan mempelajari proses yang ada pada assembly line melalui SOP (Standard Operational Prosedure) serta TIS (Toyota Instructure Sheet). Selanjutnya peneliti melakukan studi lapangan hingga ditemukan moda kegagalan pada assemblyline dan melakukan pengumpulan data berupa data primer dan data sekunder.

Setelah didapatkan data yang cukup, peneliti melakukan pengolahan data menggunakan metode FMEA, serta melakukan wawancara untuk 
mengkonfirmasi hasil dari pengolahan data yang dilakukan.

Hasil yang didapatkan menjadi dasar dalam melakukan usulan perbaikan berdasarkan prioritas kegagalan yang perlu diperbaiki.

\section{Hasil dan Pembahasan}

Pengolahan data dengan menggunakan Metode FMEA dilakukan dengan melalui beberapa tahap (Ookalkar, Joshi, \& Ookalkar, 2009), yaitu:

1. Mengidentifikasi moda kegagalan potensial dan efeknya sehingga didapatkan tingkat keparahan (Severity). Severity dilakukan untuk menganalisa resiko dengan menghitung seberapa besar/ intensitas kejadian yang mempengaruhi output proses (Souza \& Carpinetti, 2014).

2. Mengidentifikasi penyebab kegagalan potensial untuk melihat tingkat kejadian (Occurence) kegagalan pada assembly-line (Rakesh, Jos, \& Mathew, 2013).

3. Mengidentifikasi pengendalian yang telah dilakukan oleh perusahaan guna mengetahui tingkat deteksi (Detection) yang ada.

Pada Tabel 1 ditunjukkan jenis moda kegagalan pada setiap proses yang ada pada assembly-line.

Tabel 1. Moda Kegagalan

\begin{tabular}{|c|c|c|}
\hline No. & $\begin{array}{c}\text { Nama Alat/ } \\
\text { Proses }\end{array}$ & Moda Kegagalan Potensial \\
\hline 1. & $\begin{array}{l}\text { Sub-line } \\
\text { Piston }\end{array}$ & $\begin{array}{l}\text { a. Kesalahan part (tipe piston) } \\
\text { b. Part patah } \\
\text { c. Part tidak lengkap } \\
\text { d. Ring piston baret } \\
\text { e. Adanya benda asing/ part terkena kotoran (tidak presisi saat dipasang) } \\
\text { f. Kesalahan pemasangan urutan ring } \\
\text { g. Part baret } \\
\text { h. Oli belum diberikan saat proses pemasukan tekanan pin piston }\end{array}$ \\
\hline 2. & $\begin{array}{l}\text { Sub-line } \\
\text { Head }\end{array}$ & $\begin{array}{l}\text { a. Part baret } \\
\text { b. Salah pasang part } \\
\text { c. Part tidak lengkap } \\
\text { d. Pemasukan tekanan pada Stem Oil Seal kurang } \\
\text { e. Adanya benda asing/ part terkena kotoran (tidak presisi saat dipasang) } \\
\text { f. Salah pemilihan jenis oli yang digunakan } \\
\text { g. Valve bengkok } \\
\text { h. Part berubah bentuk } \\
\text { i. Karat }\end{array}$ \\
\hline 3. & $\begin{array}{c}\text { Sub-line } \\
\text { Cylinder } \\
\text { Block }\end{array}$ & $\begin{array}{l}\text { a. Part baret } \\
\text { b. Salah pemasangan part } \\
\text { c. Part tidak lengkap } \\
\text { d. Arah input tekanan oil jet tidak sesuai } \\
\text { e. Crankcap kendor } \\
\text { f. Bearing tidak lengkap } \\
\text { g. Conrod bearing kemasukan benda asing } \\
\text { h. Assembly piston assy terbalik }\end{array}$ \\
\hline
\end{tabular}

Tahap selanjutnya yaitu menentukan nilai severity (S), Occurence (O), dan detection (D). Kriteria skor dinilai dengan rentang skor 1-10 dengan masing-masing kriteria menurut Rakesh dkk (2013). Penilaian setiap moda kegagalan didapatkan melalui studi lapangan dan diskusi dengan piha-pihak terkait. Hasil pernilaian tersebut ditunjukkan pada Tabel 2.

Setelah mengetahui nilai severity, Occurence, dan detection pada setiap moda kegagalan, maka dilakukan perhitungan skor Risk Priority Number (RPN). RPN merupakan suatu indikator untuk mengukur resiko dari moda kegagalan dan menentukan tingkat skala prioritas perbaikan yang harus dilakukan terlebih dahulu (Kang, Sun, Sun, \&
Wu, 2016). Skor RPN didapatkan dari hasil perkalian nilai severity, occurence dan detection. Tabel 3. menunjukkan hasil nilai RPN dari masingmasing moda kegagalan.

Setelah dilakukan analisis dengan metode FMEA dan didapatkan masing-masing skor RPN untuk moda kegagalan yang ada, maka selanjutnya moda kegagalan tersebut dinilai berdasarkan tingkat resiko dengan melakukan risk assessment yang melihat dari dua perspektif, yaitu tingkat likelihood (kecenderungan) dan tingkat impact (dampak/resiko) (Sutrisno \& Lee, 2011).. Hasil risk assessment tersebut akan ditunjukkan pada Gambar 2. 
Tabel 2. Nilai Severity, Occurence, Detection

\begin{tabular}{|c|c|c|c|c|}
\hline Proses & Moda Kegagalan Potensial & S & $\mathbf{O}$ & D \\
\hline \multirow{8}{*}{$\begin{array}{l}\text { Sub-Line } \\
\text { Piston }\end{array}$} & Kesalahan part (tipe piston) & 6 & 2 & 6 \\
\hline & Part patah & 5 & 3 & 5 \\
\hline & Part tidak lengkap & 6 & 1 & 4 \\
\hline & Ring piston baret & 4 & 3 & 6 \\
\hline & $\begin{array}{l}\text { Adanya benda asing/ part terkena kotoran (tidak presisi saat } \\
\text { dipasang) }\end{array}$ & 5 & 2 & 5 \\
\hline & Kesalahan pemasangan urutan ring & 4 & 4 & 4 \\
\hline & Part baret & 4 & 3 & 4 \\
\hline & Oli belum diberikan saat proses pemasukan tekanan pin piston & 3 & 1 & 3 \\
\hline \multirow{8}{*}{$\begin{array}{l}\text { Sub-Line } \\
\text { Head }\end{array}$} & Part baret & 4 & 3 & 6 \\
\hline & Salah pasang part & 6 & 2 & 2 \\
\hline & Part tidak lengkap & 6 & 1 & 3 \\
\hline & Pemasukan tekanan pada Stem Oil Seal kurang & 4 & 1 & 4 \\
\hline & $\begin{array}{l}\text { Adanya benda asing/ part terkena kotoran (tidak presisi saat } \\
\text { dipasang) }\end{array}$ & 3 & 3 & 5 \\
\hline & Salah pemilihan jenis oli yang digunakan & 3 & 1 & 5 \\
\hline & Valve bengkok & 4 & 1 & 7 \\
\hline & Karat & 4 & 2 & 5 \\
\hline \multirow{8}{*}{$\begin{array}{c}\text { Sub-Line } \\
\text { Cylinder } \\
\text { Block }\end{array}$} & Part baret & 4 & 3 & 4 \\
\hline & Salah pemasangan part & 6 & 2 & 2 \\
\hline & Part tidak lengkap & 6 & 2 & 2 \\
\hline & Arah input tekanan oil jet tidak sesuai & 3 & 1 & 5 \\
\hline & Crankcap kendor & 4 & 1 & 4 \\
\hline & Bearing tidak lengkap & 5 & 2 & 2 \\
\hline & Conrod bearing kemasukan benda asing & 4 & 2 & 5 \\
\hline & Assembly piston assy terbalik & 10 & 2 & 2 \\
\hline
\end{tabular}

Tabel 3. Hasil Skor RPN

\begin{tabular}{|c|c|c|}
\hline Nama Proses & Moda Kegagalan (Failure Mode) & Skor RPN \\
\hline \multirow{8}{*}{ Sub-line Piston } & Kesalahan part (tipe piston) & 72 \\
\hline & Part rusak & 40 \\
\hline & Part tidak lengkap & 24 \\
\hline & Part Jatuh dari palet & 48 \\
\hline & Kesalahan pemasangan urutan ring & 50 \\
\hline & Adanya benda asing/ part terkena kotoran (tidak presisi saat dipasang) & 64 \\
\hline & Ring piston baret & 48 \\
\hline & Oli belum diberikan saat proses pemasukan tekanan pin piston & 9 \\
\hline \multirow{7}{*}{ Sub-line Head } & Part baret & 72 \\
\hline & Salah pasang part & 24 \\
\hline & Part tidak lengkap & 18 \\
\hline & Pemasukan tekanan pada Stem Oil Seal kurang & 16 \\
\hline & Adanya benda asing/ part terkena kotoran (tidak presisi) & 45 \\
\hline & Salah pemilihan jenis oli yg digunakan & 15 \\
\hline & Valve bengkok & 28 \\
\hline \multirow{9}{*}{$\begin{array}{c}\text { Sub-line Cylinder } \\
\text { Block }\end{array}$} & Karat & 40 \\
\hline & Part baret & 48 \\
\hline & Salah pemasangan part & 24 \\
\hline & Part tidak lengkap & 24 \\
\hline & Arah input tekanan oil jet tidak sesuai & 15 \\
\hline & Crankcap kendor & 16 \\
\hline & Bearing tidak lengkap & 20 \\
\hline & Conrod bearing kemasukan benda asing & 32 \\
\hline & Assembly piston assy terbalik & 40 \\
\hline
\end{tabular}


Berdasarkan hasil skor RPN dan hasil risk assessment, maka dilakukan analisis dan pemecahan masalah seperti berikut:

1. Analisis Kesalahan Part (Tipe Piston) pada Sub-Line Piston

Kegagalan yang terjadi adalah kesalahan dalam pemilihan part piston crown untuk mesin TR dan TR-K pada saat operator melakukan persiapan assembly Piston yang meletakkan part-part penyusun Piston pada suatu pallet. Kegagalan tersebut dikarenakan kurangnya deteksi kegagalan yaitu hanya berupa visual check dan marking yang mengandalkan pada keahlian dan ketelitian operator. Deteksi juga dilakukan dengan adanya perbedaan aksen pada bentuk mesin TR dan TR-K.

2. Kasus Kegagalan Adanya Benda Asing pada $\underline{\text { Part. }}$

Kegagalan berupa adanya benda asing/part terkena kotoran sehingga menjadi tidak presisi pada saat dipasang, merupakan kegagalan yang memiliki skor RPN yang cukup tinggi, yaitu hingga mencapai nilai 62 yang terjadi pada Sub-Line Piston maupun Sub-Line Head. Kegagalan ini disebabkan karena tingkat deteksi yang masih rendah dan tingkat occurence yang cukup besar atau dikatakan cukup sering terjadi.

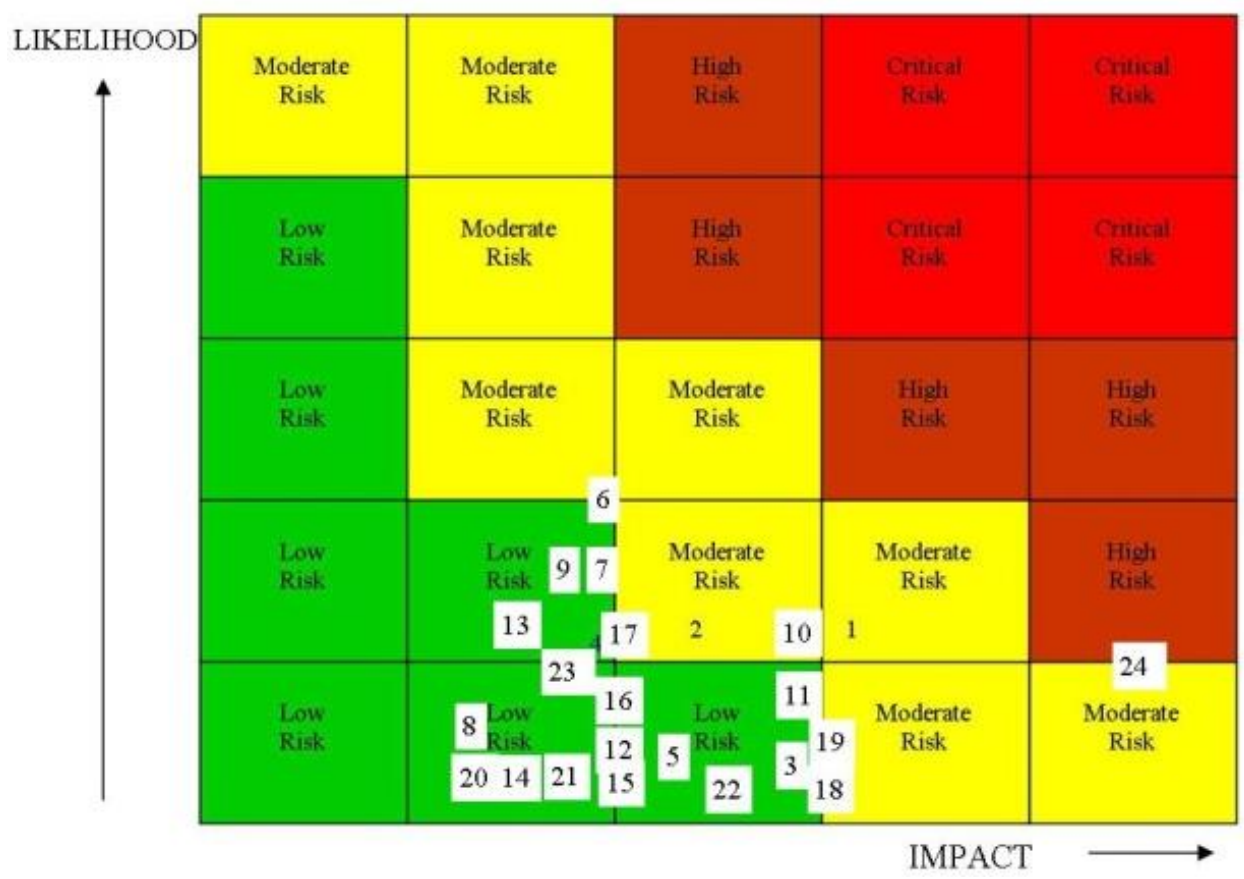

Gambar 2. Hasil Risk Assessment

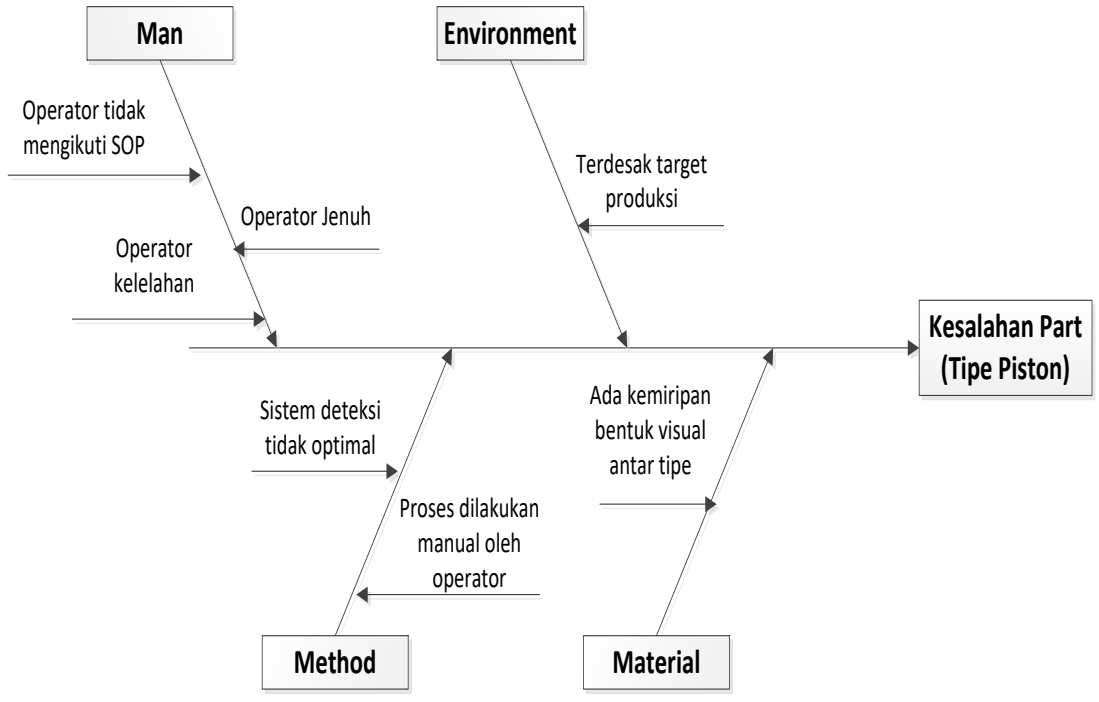

Gambar 3. Fishbone Kesalahan Part 
Dampak kegagalan ini adalah terjadinya guncangan pada mesin atau menimbulkan suara yang tidak halus pada saat mesin dioperasikan.

Moda kegagalan ini dapat dijadikan prioritas untuk melakukan kegagalan karena kegagalan ini cukup sering terjadi dan pencegahannya cenderung tidak rumit sehingga dapat dilakukan dengan cepat dan dengan biaya yang rendah.

3. Kasus Assembly Piston Assy Terbalik pada Sub-Line Cylinder Block

Kasus ini merupakan salah satu kasus yang dapat dikatakan diprioritaskan untuk dilakukan perbaikan, walaupun berdasarkan rekap hasil skor RPN, tidak menunjukkan nilai yang tinggi, tetapi dampak/ severity yang ditimbulkan sangat besar, yaitu dapat berpotensi pada kegagalan yang dirasakan langsung oleh konsumen.

Kegagalan ini terjadi akibat adanya kesalahan dalam pemasangan piston assy pada cylinder block. Berdasarkan tipe mesin yang dihasilkan oleh PT.
TMMIN, yaitu tipe TR dan TR-K, maka terjadi kegagalan yaitu pemasangan piston assy dan cylinder block yang sebenarnya memiliki tipe mesin yang berbeda. Kasus yang terjadi adalah pemasangan piston assy tipe TR pada engine cylinder block tipe TR-K. Hal tersebut dapat berdampak pada mesin pada saat dioperasikan dapat menghasilkan engine noise.

Berdasarkan analisis yang telah dilakukan maka didapatkan usulan perbaikan dalam upaya minimasi tingkat cacat yang terjadi. Kasus piston Assy terbalik yang terjadi di Sub-Line Cylinder Block merupakan kegagalan yang difokuskan peneliti dalam melakukan usulan perbaikan, dilihat dari tingkat severity dan usulan yang diajukan oleh pihak dari PT. TMMIN yang terkait dalam rangka improvement yang harus segera dilakukan. Pada tabel 4 akan dijelaskan mengenai alternatif perbaikan yang dilakukan, yaitu terdiri dari dua alternatif dengan analisis faktor pertimbangan yang mempengaruhi yang mana permasalahan yang ada sebelumnya adalah sistem dalam input ID varian dari tipe mesin masih dilakukan secara manual oleh operator.

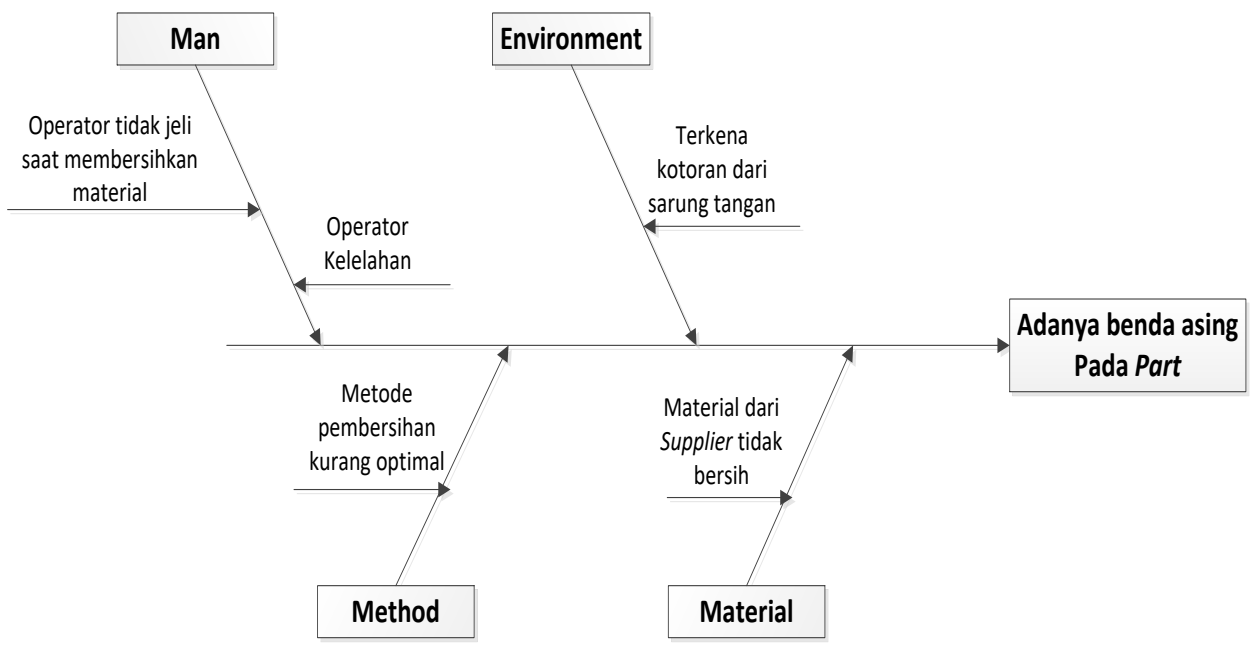

Gambar 4. Fishbone Kegagalan Adanya Benda Asing pada Part

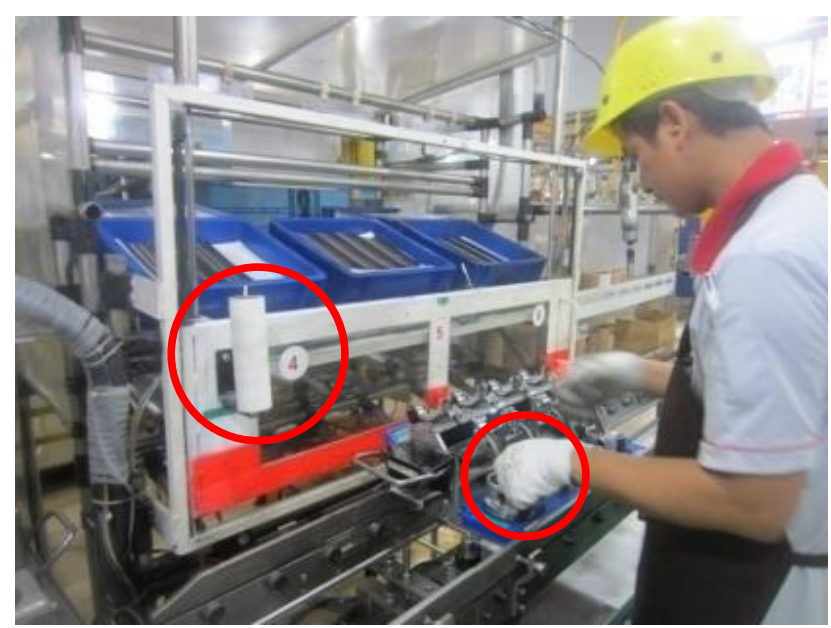

Gambar 5. Pencegahan Adanya Benda Asing pada Part 
Tabel 4. Alternatif Perbaikan

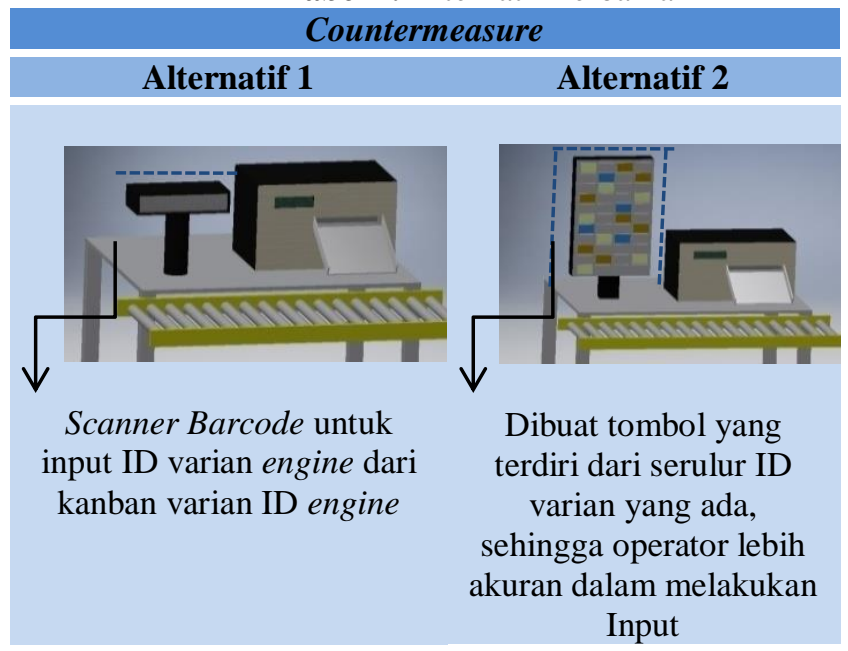

Tabel 5. Faktor Pertimbangan Alternatif

\begin{tabular}{|c|c|}
\hline Faktor & Alte \\
\hline Safety & Tidak berhubungan \\
\hline Quality & $\begin{array}{c}\text { Pencegahan kesalahan input ID } \\
\text { engine }\end{array}$ \\
\hline Productivity & $\begin{array}{l}\text { Operator input ID varian engine } \\
\text { dengan sistem scanning bare }\end{array}$ \\
\hline Cost & $\begin{array}{c}- \\
\text { (peneliti belum dapat melakukan } \\
\text { dari faktor cost) }\end{array}$ \\
\hline Environtment & $\begin{array}{l}\text { Layout stasiun kerja lebih simpel } \\
\text { memakan banyak space }\end{array}$ \\
\hline \multicolumn{2}{|c|}{$\begin{array}{l}\text { Pada tabel } 5 \text { merupakan faktor pertimbangan } \\
\text { yang dapat menjadi pembanding antar kedua } \\
\text { alternatif. } \\
\text { Dari pertimbangan faktor alternatif perbaikan } \\
\text { sesuai dengan Tabel 5, maka dapat disimpulkan } \\
\text { alternatif yang digunakan adalah alternatif 1, yang } \\
\text { mana lebih menunjuang pada sisi efektivitas dan } \\
\text { efisiensi dari kinerja operator pada sub-line } \\
\text { cylinder block. }\end{array}$} \\
\hline
\end{tabular}

\section{Kesimpulan}

Defect yang mungkin terjadi pada test bench room dapat disebabkan oleh berbagai moda kegagalan yang ada pada assembly-line. Untuk mengurangi jumlah defect yang terjadi, maka perlu dilakukan perbaikan. Perbaikan yang diprioritaskan berdasarkan pada skor RPN.

Hasil penelitian menunjukkan beberapa prioritas tindakan yang dilakukan yaitu untuk moda kegagalan berupa kesalahan part (tipe piston), adanya benda asing pada part dan kasus terbaliknya Assembly Piston Assy. Selain dilihat dari skor RPN, perbaikan terhadap ketiga kegagalan tersebut juga dilakukan dengan pertimbangan tindakan yang realistis dari segi waktu dan biaya.

\section{Alternatif 2}

Tidak berhubungan

Pencegahan kesalahan input ID varian

Operator input ID varian masih secara manual

(peneliti belum dapat melakukan analisis dari faktor cost)

Layout stasiun kerja lebih kompleks dan menyebabkan perlunya space yang lebih besar

Usulan perbaikan yang dilakukan peneliti bertujuan untuk mengurangi dampak kegagalan atas terjadinya kesalaha Assembly Piston Assy yang terbalik. Alternatif perbaikan yang diusulkan yaitu membangun sistem Scanner Barcode untuk input ID varian engine dari kanban varian ID engine. Usulan tersebut digunakan untuk mengurangi kemungkinan terjadinya kegagalan akibat human error. Untuk mengatasi human error tersebut, peneliti memberikan usulan perbaikan berupa perubahan sistem deteksi secara otomatis, yaitu dengan sistem barcode sehingga operator tidak melakukan aktivitas secara manual.

\section{Saran}

1. Peneliti perlu benar-benar melakukan studi lapangan sehingga memahami proses dan mengetahui secara pasti kegagalan-kegagalan apa yang mungkin terjadi pada proses yang diamati, sehingga didapatkan usulan perbaikan yang sesuai dan dapat diterapkan pada sistem nyata.

2. Jika menggunakan data historis, sebaiknya data yang diolah merupakan data time series yang belum lama atau minimal 1 tahun terakhir. 


\section{Daftar Pustaka}

Dudek, M., \& Burlikowska. (2011). Application of FMEA Method in Enterprise Focused on Quality. Journal of Achievement in Materials and Manufacturing Engineering, 89-102.

Kang, J., Sun, L., Sun, H., \& Wu, C. (2016). Risk assessment of floating offshore wind turbine based on correlation-FMEA. Ocean Engineering, 382-388.

Khodijah, S. L. (2015). Analisis Faktor-Faktor Penyebab Kerusakan Produk Pada Proses Cetak Produk. (Studi kasus pada Majalah SAKINAH PT. Temprina Media GrafikaJawa Pos Grup-Semarang). Semarang: Universitas Diponegoro.

Kotler, P., \& Keller, K. L. (2011). Marketing Management (14th edition). Pearson.

Mayangsari, D. F., Adianto, H., \& Yuniati, Y. (2015). Usulan Pengendalian Kualitas Produk Isolator Dengan Metode Failure Mode And Effect Analysis (FMEA) dan Fault Tree Analysis (FTA). Jurnal Online Institut Teknologi Nasional, 81-91.

Ookalkar, A., Joshi, A. G., \& Ookalkar, S. D. (2009). Quality Improvement in Haemodialysis Process using FMEA. International Journal of Quality \& Reliability Management, 817-830.
Rakesh, R., Jos, B. C., \& Mathew, G. (2013). FMEA Analysis for Reducing Breakdowns of a Sub System in the Life Care Product Manufacturing Industry. International Journal of Engineering Science and Innovative Technology .

Saad, G. H., \& Siha, S. (2000). Managing Quality: critical links and a contingency model. International Journal of Operations \& Production Management, 1146-3577.

Souza, R. V., \& Carpinetti, L. C. (2014). A FMEAbased approach to prioritize waste reductionin lean implementation. International Journal of Quality \& reliability Management, 346-366.

Sutrisno, A., \& Lee, T.-R. (2011). Service Reliability Assessment Using Failure Mode and Effect Analysis (FMEA): Survey and Opportunity Roadmap. International Journal of Engineering, Science and Technology, 25-38.

Weckenmann, A., Akkasoglu, G., \& Werner, T. (2015). Quality management - history and trends. The TQM Journal, 281-293.

Williams, R., Bertsch, B., Dale, B., Wiele, T. v., Iwaarden, J. v., Smith, M., et al. (2006). Quality and Risk Management: What are the key issues? The TQM Magazine, 6786. 